\title{
A POVIAT GOVERNOR AS A PARTY TO THE AGREEMENT TRANSFERRING THE OWNERSHIP OF OBJECTS AND PROPERTY RIGHTS TO THE STATE TREASURY OR A LOCAL GOVERNMENT UNIT IN EXCHANGE FOR TAX ARREARS
}

\author{
MAEGORZATA OFIARSKA ${ }^{l}$
}

\begin{abstract}
The aim of the article is the analysis and evaluation of the legislation applicable within the scope of using a specific manner of expiry of a tax liability, which is transferring of the ownership of an object or property rights by the obligor to the State Treasury or a local government unit and, thus, carrying out of the liability in kind. The main objective of the study has been achieved by proving that, depending on the type of tax arrears, i.e. due to the State Treasury or a poviat, what changes the scope of powers and duties, which are the essence of the functions performed by a poviat governor. As a result of the conclusion of the agreement transferring the ownership of objects and property rights to the State Treasury in exchange for tax arrears, the tax liability expires, yet, it is executed only exceptionally in kind and not in a pecuniary form. The study uses the dogmatic-legal method in order to examine the normative material and the achievements of the doctrine as well as the empirical method necessary for the examination of the court rulings.
\end{abstract}

Keywords

Poviat governor; tax arrears; agreement; State Treasury; local government unit

\section{JEL Classification: H7, K34, K12}

1 Professor of University of Szczecin, Doctor of Law, Head of the Department of Local Government Law, Faculty of Law and Administration, University of Szczecin, Poland. The Author of over 250 publications, including 10 books, 40 articles, 94 studies in joint works and other electronic publications. Specialises in local government law and administrative enforcement proceedings. He is a member of Information and Organization Centre for the Research on the Public Finances and Tax Law in the Countries of Central and Eastern Europe. Contact email: malgorzata.ofiarska@usz.edu.pl. 


\section{Introduction}

The aim of the study is the analysis and evaluation of the legislation applicable within the scope of using a specific manner of expiry of a tax liability, which is transferring of the ownership of objects or property rights by the obligor to the State Treasury or a local government unit (ins short LGU) and, thus, carrying out of the liability in kind. A tax liability is, in fact, carried out in the financial form because one of the most significant features of a tax mentioned under Art. 6 of the Tax Ordinance Act (further TOA) is the financial nature of this regulatory, gratuitous, compulsory and non-returnable performance for the benefit of the State Treasury, a voivodeship, poviat or commune. Taxes belong to the category "finance", which only refers to economic phenomena connected with gathering and division of financial resources. Thus, benefits in kind, personal services, objects and property rights are not taxes. In general, a tax shall not have the in-kind form (Gomułowicz, 2016: 146). Currently, the form of settling tax liabilities in kind has not been completely eliminated. It has remained in a rudimentary form as a specific manner of being exempted from a tax liability. Its use enables the State Treasury or any other Authorized entity to acquire some entities of interest, thus, increasing the national property (Bouvier, 2000: 24).

The financial nature of the tax is not questioned currently. Nevertheless, the obliged entity may sometimes be exempted from the obligation to pay tax through the provision of some benefits in kind (Brzeziński, 2001: 31). In a special situation, the legislator allows a possibility to perform a tax liability by transferring the ownership of objects or property rights (Brzeziński, Olesińska 2014: 31). This, nevertheless, requires the use of proper procedures and the necessary initiative within this scope on the side of the obliged entity (taxpayer). As a part of the applicable procedures, a specific role is ascribed to a poviat governor (pl. starosta), who represents respectively the interest of the State Treasury (if the tax receivable should enter the state budget) or the interest of the poviat (if the receivable for the specific public levy should enter the poviat budget). In the other cases, the interests of the respective LGU are represented by a commune administrator (pl. wójt), a town mayor (pl. burmistrz) or a city mayor (pl. prezydent miasta) (in the case of any receivables due to a commune) or a voivodeship governor (pl. marszałek województwa) (in the case of any receivables due to the voivodeship local government).

The study is to prove that a poviat governor - as a party to an agreement with a taxpayer concerning a transfer of the ownership of objects or property rights in exchange for taxpayer's tax arrears - enters into multilateral relationships with a taxpayer, the head of a tax office as well as the poviat executive body and legislative body. Only a poviat governor appears in a double role, i.e. as a representative of the 
A Poviat Governor as a Party to the Agreement Transferring the Ownership...

interests of the State Treasury or the poviat. A tax liability for the benefit of a poviat shall not be understood in a narrow manner and limited only to a tax. The model of poviat's own revenues adopted in Poland ${ }^{2}$ is not perfect because it does not include any local taxes, but only fees the payments of which constitute the revenues of a poviat pursuant to separate provisions of the act (e.g. waste storage and warehousing fees $^{3}$, mining fees for searching for and recognizing of a hydrocarbon deposit ${ }^{4}$, fees for activities related to maintaining of the poviat geodetic and cartographic resources $^{5}$, fees for issuing of vehicle registration cards ${ }^{6}$ ). The phrase "expiry of a tax liability" used in the content of Art. 66/1 of TOA should refer not only to a tax but also to any other public levies whereto the provisions of this act apply. Pursuant to Art. 2 of TOA, the provisions of this act apply to taxes, fees and nontax dues to the state budget and budgets of LGU, which the tax authorities or any other authorities empowered based on separate provisions, are entitled to establish or determine. The subjective and objective frames of applying the provisions of Tax Ordinance have been determined relatively broadly (Brzezicki, Morawski, 2009: 514), and, thus, the phrase "expiry of a tax liability" should also refer to other public levies.

The analysis and evaluation of the applicable legislation is supposed to lead to verification of the thesis, pursuant to which a rational legislator creates conditions facilitating the performance of a tax liability, even in a specific manner due to the fact of a temporary or definitive loss of the ability to settle the liabilities with the use of any means of payment. The possibility to use a specific manner of a tax liability settlement, which is transferring of the ownership of objects or property rights by the obligor to the State Treasury or LGU, simultaneously protects the obligor's interests because it does not lead to any additional encumbrances related to performance of the liability and, in particular, any enforcement costs or default interest. The study uses the dogmatic-legal method (examination of the normative material and the achievements of the doctrine) as well as the empirical method (examination of the court rulings). It has been established, first of all, that the application of this specific manner of performing a tax liability (performance in kind) is permissible upon an obligor's request and consent of the entity representing the interests of the State Treasury or LGU. Both conditions have to be fulfilled jointly (the obligor's request and the tax obligee's consent). The dual role of a poviat governor within this scope is shaped by the provisions of the local government constitutional law, tax law and local government financial law (also determining the sources of poviats' revenues).

Cf Art. 5 of the Act on revenues of local government units.

Cf Art. 402 of the Environmental Protection Law Act.

Cf Art. 141 of the Geological and Mining Law Act.

Cf Art. 41b of the Geodetic and Cartographic Law Act.

Cf Art. 77 of the Road Traffic Law Act. 
Significant findings have been made based on the achievements of the doctrine, including the doctrine of the local government law and the tax law. So far, there has been no study in the literature on the subject where the legal position and the functions of a poviat governor would be analysed in such detail in the context of applying a specific manner of expiry of tax arrears through a contractual transfer by a taxpayer of the ownership of objects or property rights for the benefit of the State Treasury or a poviat.

\section{Selected Problems Concerning Status of Poviat Governor in Local Government Law Tax Law}

The legal position of a poviat governor is mostly shaped by all the provisions of the Poviat Local Government Act (further PLGA). A poviat governor elected by the legislative body of a poviat is a member of the poviat board (the poviat executive body), being its chairman (Art. 26/2 of PLGA). A poviat governor organizes the work of the poviat board and the poviat office, supervises the current affairs of the poviat and represents the poviat outside, develops an operational plan of flood protection as well as announces and recalls a flood emergency and alarm (Art. 34 of PLGA). It is a public administration authority of the first instance issuing administrative decisions in individual matters within the scope of public administration (Art. 38 of PLGA).

Pursuant to the provisions of Art. 13/1/1 of TOA, a poviat governor is a tax authority of the first instance as regards public charges and non-tax budget dues which are the sources of poviat's own revenues (e.g. fees for issuing of vehicle registration cards). In these cases, a poviat office shall not replace a poviat governor as an authority as it is only an auxiliary apparatus (office), understood as an organized group of people useful for helping an administrative authority to perform its functions. Thus, it shall not enter the competences of a tax authority (Voivodeship Administrative Court: III SA/Wa 2972/05). Pursuant to Art. 14 of TOA, a poviat governor is Authorized to issue individual interpretations of tax law provisions in tax matters of his competence. In such an event, a fee for the application for issuing of an individual interpretation constitutes the revenue of the poviat budget. An applicant may not freely select an authority issuing the interpretation (Viovodeship Administrative Court: I SA/Sz 1212/14).

The most significant thing, from the point of view of the subject matter, is two groups of poviat governor's competences. The first group shall include the poviat governor's competencies related to the representation of the poviat outside, including tasks connected with executing of the poviat's budget by the poviat board 
A Poviat Governor as a Party to the Agreement Transferring the Ownership...

chaired by the poviat governor. The activities related to the collecting of budget revenues are included within the limits of the task involving budget execution. Within the meaning of the constitutional act, representation is understood as the performance of public law activities and not civil law activities. Representation in the proper meaning, i.e. filing of declarations of intent within the scope of the civil law and procedural activities is regulated by special provisions (Dolnicki, 2003: 62). This category of regulations may include the provisions of Art. 66/2/2 of TOA permitting a transfer of the ownership of objects or property rights to a poviat in exchange for tax arrears (fees, non-tax budget dues) constituting poviat's budget revenues. In such an event, the ownership is transferred based on an agreement concluded between a poviat governor and a tax payer.

Except for its own tasks, a poviat also performs tasks within the scope of government administration, the performance of which is connected with the second group of poviat governor's competences. The types and the scope of these tasks are determined by agreements concluded by a poviat with government administrative authorities or provisions of separate acts. In the analyzed case, an important example of the statutory determination of the issues included within the scope of poviat's activities, as a task from the catalog of government administration performed by the poviat are the provisions of Art. 66/2/1 of TOA. Pursuant to this provision, in order to lead to the expiry of tax arrears as regards taxes constituting the state budget revenues, an agreement is concluded on transferring of the ownership of object or property right to the State Treasury. The term "tax" used in this provision should be understood in a manner specified under Art. 3/3 of TOA, i.e. broadly, and, therefore, it should also include advance tax payments (characteristic for income taxes), tax installments (if tax regulations provide for the payment of a tax in installments), fees and non-tax budget dues. This means that any tax arrears, i.e. any overdue amounts of taxes, advance tax payments, tax installments, fees or non-tax budget dues may expire in the manner regulated in Art. 66 of TOA. The agreement with a taxpayer in such a situation is concluded by a poviat governor (performing the task within the scope of government administration) upon consent of the competent head of a tax office.

Literature often points to multidimensionality and complexity of the functions performed by a poviat governor as well as the legal position thereof, in particular in relation to poviat bodies (the council and the board). It is due to the performance of specific tasks within the scope of government administration by a poviat that the position of a poviat governor is specifically conditioned in relation to local and central government structures (Niemczuk, 2011: 75-93; Bielecki, 2010: 9-21). A reflection of this specific position of a poviat governor and the complex relations 
is e.g. the provisions of Art. 66 of TOA permitting the method of expiry of a tax liability in an in-kind manner, i.e. without using any means of payment.

\section{Material Scope of Applying Art. 66 of TOA}

Specification of the material scope of applying Art. 66 of TOA is possible by means of determining the limits of the term "tax arrears". It is necessary to emphasize that, in spite of the inclusion, in the content of Art. 66 of TOA, of a general statement about "a specific case of expiry of a tax liability" in further provisions of the regulation, the legislator refers it only to one form of a tax liability, which is tax arrears. The scope of the term "tax arrears" has been determined in Art. 51 of TOA. The term is to be understood as tax, advance tax payment, and tax installment if these dues have not been paid by the payment deadline. Taking into consideration, previously quoted Art. $3 / 3$ of TOA, tax arrears may also arise due to an overdue fee or non-tax budget due (Olesińska, 2009: 118). Furthermore, tax arrears also include any dues in respect of taxes, advance tax payments and tax installments which have not been paid by the payment deadline by a taxpayer or a payment collector. The essence of tax arrears is, thus, lack of payment of a specific amount due by the payment deadline. The terms "tax liability" and "tax arrears" shall not be considered equal because this may lead to serious interpretation doubts (judgment of the Voivodeship Administrative Court: I SA/Rz 67/14). Tax arrears are a specific form of a tax liability, i.e. a liability for which the payment deadline has lapsed ineffectively.

Tax arrears are of an objective nature and their arising, as well as existence, shall be connected to a failure to pay the whole or a part of a tax (advance tax payment, tax installment, fee, non-tax budget due) by the payment deadline. They only constitute a tax liability that has not been fulfilled as a whole or in part (judgment of the Voivodeship Administrative Court: III SA/Wa 861/10). It has been accurately assessed that tax arrears are not an independent tax liability but arise as a consequence of a failure to fulfill a tax payer's tax liability (Burzyński, 2012: 25). Pursuant to Art. 52 and 52a of TOA, the following shall be treated as tax arrears:

- overpayment or tax return indicated in a tax statement unduly or in an amount higher than the amount due;

- amounts of overpayments or taxes previously returned to a taxpayer and not returned by the taxpayer within 30 days of being delivered a decision specifying a return obligation;

- the remuneration of taxpayers or tax collectors collected unduly or in the amount higher than the amount due. 
A Poviat Governor as a Party to the Agreement Transferring the Ownership...

Due to the fact that default interest is a consequence of the arising of tax arrears, their legal existence is connected with the obligation from which they result (Ciecierski, 2011: 97). Default interest is not an independent benefit separated from tax arrears. It is of accessory nature in relation to tax arrears. It may only arise when tax arrears arise. Expiry of the arrears as a whole or in part result in expiry of the default interest as a whole or in part (Etel, 2017: 507). The special manner of expiry of tax arrears regulated in Art. 66 of TOA refers, thus, not only to the principal amount of tax arrears (e.g. due to a tax unpaid by the payment deadline) but also to the default interest calculated on the overdue amount. Transferring an object or a property right to the State Treasury or LGU based on an agreement, a taxpayer may, in this manner, lead to the expiry of a tax liability in the form of tax arrears and default interest or a respective part of tax arrears and the corresponding part of default interest. Such an assessment of the regulations included in Art. 66 of TOA is Authorized by the provisions of Art. 66/5 of TOA ordering the relevant application of Art. 55/2 of TOA stipulating that in the event when the payment made does not cover the amount of tax arrears together with default interest, the amount will be proportionally credited to tax arrears and default interest in relation to the amount of tax arrears to the amount of default interest on the date of payment.

Pursuant to the findings made, the manner of expiry of a tax liability regulated in Art. 66 of TOA shall not be applied to tax payer's current or future tax liabilities and, thus, to any for which the payment deadline has not elapsed yet. On the other hand, taking into consideration the scope of the term "tax arrears" determined by the provisions of Art. 51-52a of TOA, it may be assumed that a specific manner of expiry of this form of a tax liability determined in Art. 66 of TOA is permissible both with regard to typical tax arrears mentioned in Art. 51 of TOA as well as with regard to other amounts due to the State Treasury or LGU, which a taxpayer (or collector) has received unduly or in the amount higher than the amount due and has not returned within the specified time limit.

A specific manner of expiry of tax arrears regulated in Art. 66 of TOA may be applied to any existing (i.e. not overdue) tax arrears regardless of their amount or the moment of their arising as well as regardless of the legal form of the original liability (tax, tax installment, advance tax payment, fee, non-tax budget due). It is also not important whether, at the moment of application of this manner of settlement of tax arrears, the obligor is subject to arrears on account of one or many tax titles. It is also of no significance whether the obligor's tax arrears are the result of a conducted business activity or the effect of various events related to the personal sphere. 


\section{Agreement on Transferring of Ownership of Objects or Property Rights}

The conclusion of an agreement transferring the ownership of objects or property rights to the State Treasury or LGU in exchange for tax arrears may only occur on the initiative of a taxpayer subject to such arrears. A material expression of this initiative is an application filed by a tax payer with a poviat governor. In the application, a taxpayer shall indicate the types of tax arrears as well as the objects or property rights intended to be transferred in order to lead to the expiry of these arrears. The conclusion of the agreement regulated in Art. 66 of TOA shall not be initiated by any other entity (Siemieniako, 2008: 45) ${ }^{7}$, including but not limited to a tax authority or a poviat governor representing the interests of the State Treasury. A tax authority or a poviat governor may, nevertheless, inform a taxpayer that this specific manner of performance of a tax liability is regulated in the tax law.

Transferring of the ownership of objects or property rights to the State Treasury or LGU in exchange for tax arrears may be effected only based on an agreement concluded between a taxpayer and a poviat governor (in the event when a poviat governor represents the interests of the State Treasury, conclusion of the agreement is only possible after obtaining a consent from the competent head of a tax office). Consent of the head of a tax office is a form of controlling the activities of a poviat governor representing the interests of the State Treasury.

For many years, a scientific discussion has continued as regards the legal status of such an agreement. In the doctrine, there are varied views within this scope. Taking into consideration the fact that, in specific cases, the conclusion of the agreement requires the consent of the competent head of a tax office, it has been concluded that the consent not only constitutes an inherent element of the performed legal activity but is also an activity within the scope of the public law. The legal construction regulated in Art. 66 of TOA is internally complex, yet its basic element remains a civil law agreement, which additionally requires a consent of the competent head of a tax office to become effective (Borszowski, 2003: 16). This means that transferring of the ownership of objects or property rights in exchange for tax arrears occurs under private law, yet this does not change the essence of the regulation included in Art. 66 of TOA, which introduces a specific mechanism of expiry of a tax liability and does not refer to business transactions (Gomulowicz, 2008). Other Authors consider this to be an agreement of an ambiguous nature because some of its features are characteristic both for nominate agreements (sale agreement) as well as innominate agreements (Bielenik, 2000: 57; Ślifirczyk, 1998: 6).

7 A different view permitting the initiative of a different entity than a taxpayer was expressed by A. Huchla (2000: 52). 
A Poviat Governor as a Party to the Agreement Transferring the Ownership...

In court rulings, in accordance with the dominant assessment, the agreement specified in Art. 66 of TOA is of a civil law nature (e.g. Supreme Administrative Court: I FSK 555/13), yet it is not a classic civil law agreement (judgment of the Supreme Administrative Court: I FSK 1635/10). Simultaneously, the courts emphasize that the parties using the contractual form of transferring the ownership of objects or property rights do not perform the equivalent legal act (Supreme Administrative Court: I FSK 501/06). As a result of the conclusion of this agreement, a special (e.g. in-kind) manner of collecting taxes or another public levy is effected. Nonequivalence of the activity of tax liability settlement excludes its inclusion in paid supply of goods (Voivodeship Administrative Court: I SA/ Po 718/13; Voivodeship Administrative Court: III SA/GI 1312/12) and, thus, it shall not be subject to the tax on goods and services. A taxpayer settling the tax in the manner specified in Art. 66 of TOA fulfills the liability under the tax act, not obtaining any equivalent in the form of payment of the selling price, which is the immanent feature of bilateral, mutual civil law acts (Supreme Administrative Court: I FSK 434/10).

Within this scope, the courts take into consideration the arguments included in the resolution of 7 judges (Supreme Administrative Court: I FPS 2/07), referring to the legal definition of a tax formulated in art. 6 of TOA. A tax is not any pecuniary performance that may be obtained "in exchange" for another performance because its basic feature is the unilateralness and the nonequivalence of the tax. A taxpayer settling a tax does not obtain any benefit. Similarly, the state or LGU authorities, consenting to the collection of tax arrears arising as a result of a failure to pay the tax by the payment deadline with the use of the contractual form of transferring the ownership regulated in Art. 66 of TOA do not perform the equivalent legal act. They only perform their competences within the scope of enforcement of public revenues within the state empire sphere even if this occurs with the use of private law instruments, i.e. an agreement concluded between a taxpayer and a poviat governor performing the tasks within the scope of government administration/ cooperating with the head of a tax office (Supreme Administrative Court: I FPS 2/07). Thus, there are no features characteristic for business transactions as regards the transaction performed between a tax payer and a poviat governor representing the interests of the State Treasury or a poviat (Wołowiec, 2012: 25).

Neither does transfer of the ownership of objects or property rights for the benefit of the State Treasury or LGU in exchange for tax arrears on account of taxes result in any revenue on the side of a taxpayer who would be subject to income tax (personal or corporate income tax respectively). The essence of the regulation included in Art. 66 of TOA does not refer to business transactions but only introduces one special mechanism of collecting a tax in the form of tax arrears. Conclusion of such 
an agreement does not generate any revenue on the side of a taxpayer or any other benefit based on a civil law relationship, but results in performance of the liability of a tax nature (judgement of the Supreme Administrative Court: I SA/Po 3066/14; Voivodeship Administrative Court in Gliwice: I SA/GI 552/16).

It has been mentioned above that the activities of a poviat governor concerning the conclusion of the agreement under discussion are controlled by the head of a tax office. The provisions of Art. 66/3b of TOA include a competence norm determining the liability of the head of a tax office to give or refuse consent for transferring of objects or property rights for the benefit of the State Treasury with a view to the expiry of a tax liability on account of taxes constituting the state budget revenues. In the provisions of Art. 66/3a of TOA, the legislator specifies the procedure of transferring the ownership of objects or property rights for the benefit of the State Treasury involving the conclusion of an agreement between a taxpayer and a poviat governor and, subsequently, giving of a consent for its conclusion by the head of a tax office. Such a sequence of activities of a poviat governor is determined by the obligation specified in Art. 66/3a of TOA. A poviat governor shall notify the competent head of a tax office of concluding the agreement, at the same time sending a copy thereof. As a result, the effectiveness of the agreement concluded between a taxpayer and a poviat governor arises subject to the condition precedent and, thus, only upon giving of a consent by the head of a tax office through a decision. A refusal to transfer objects or property rights for the benefit of the State Treasury in exchange for tax liabilities on account of taxes constituting state budget revenues results in the ineffectiveness of the agreement (Supreme Administrative Court: II FW 2/14).

In the event of the contractual transfer of the ownership of objects or property rights to a poviat in exchange for tax arrears on account of public levies constituting state budget revenues, the position of a poviat governor as a party concluding such an agreement is independent, i.e. does not require consent of any other bodies, including a poviat council. In the event of concluding the agreement, a poviat governor issues a decision determining the amount of expiry of tax arrears. The activities involving conclusion of the agreement and issuing of the decision on expiry of tax arrears are included within the limits of the exclusive competences of a poviat governor.

The provisions of Art. 66 of TOA are a special regulation in relation to Art. 12/8/a of PLGA, pursuant to which adoption of resolutions on property issues of a poviat concerning the principles of acquiring real property are exclusively within the competences of a poviat council unless otherwise provided in special acts. The circumstances that a poviat board intends to maintain full control over individual cases of acquiring real property is of no legal significance in a situation where 
A Poviat Governor as a Party to the Agreement Transferring the Ownership...

statutory regulations do not grant any competences to it to express a consent to such a transaction (or adopt a resolution generally specifying the principles of acquisition) each time (Voivodeship Administrative Court: II SA/Łd 1518/03). The principles of acquiring objects or property rights by a poviat from a taxpayers in exchange for tax arrears are specified in Art. 66 of TOA and, thus, the provision, as lex specialis to Art. 12/8/a of PLGA, prevail over the constitutional regulation, which means that effective performance of a legal act by a poviat governor within the scope normalized in Art. 66 of TOA does not require any previous consent of a poviat council. Simultaneously, Art. 66/2/2 of TOA does not create any obligation, as regards a poviat governor, to obtain the consent of a poviat council for acquisition of real property pursuant to the procedure specified in Art. 66 of TOA. Moreover, it must be emphasized that the provisions of Art. 12/8/a of PLGA do not grant any competences to a poviat council within the scope of determining the principles concerning the acquisition of movable property for the benefit of a poviat.

Pursuant to the provisions of Art. 66/3 of TOA, an ordinary written form is determined by the agreement on transferring of objects or property rights by a taxpayer for the benefit of the State Treasury or a LGU in exchange for tax arrears, yet, due to the nature of the act (agreement) transferring the ownership of real property, it should be concluded in a special form, i.e. in the form of a notarial deed, pursuant to Art. 158 read in connection with Art. 73 of the Civil Code (Morawski, 1998: 242).

\section{Moment of Expiry of Tax Liability}

In the event of a contractual transfer of the ownership of objects or property rights by a taxpayer for the benefit of the State Treasury or a LGU in exchange for tax arrears, the expiry date of a tax liability is considered to be the date of transferring the ownership of objects or property rights. Therefore, the conclusion of a preliminary agreement, being an agreement of an organizational (preparatory) nature, does not lead to the expiry of a tax liability. The preliminary agreement shall be distinguished from the definitive agreement, which accomplishes the objective intended by the parties. The accomplishment of the objective is only possible in the event of providing the performance based on the final agreement (Voivodeship Administrative Court: I SA/Po 846/10). Expiry of a tax liability occurs on the date of transferring of the ownership of an object or a property right. Transferring of the ownership of the objects indicated as to their identity occurs on the date of concluding the agreement, the object indicated as to their type - on the date of transferring of their possession, whereas transferring of the right occurs in a manner resulting from its essence (Dauter, 2002: 41). 
A reference from Art. 66/5 of TOA containing an order to apply the provisions of Art. 55/2 of TOA accordingly as well as lack of references to Arts. 72-80 of TOA mean that the value of objects or property rights transferred to the State Treasury or a LGU in exchange for tax arrears on account of taxes constituting the revenue of the state or a LGU budget shall be equal to or higher than the amount of tax arrears (Drela, 2014: 26). The scope of Art. 72 of TOA regulating the essence and the manner of arising of a tax overpayment does not include transferring of the ownership of objects or other property rights resulting in expiry of a tax liability based on Art. 59/1/6 of TOA being, however, only a different manner of expiry of a tax liability than the tax payment. The provisions of Art. 72 of TOA regulate only two instances (from among eleven mentioned in Art. 59/1 of TOA), which provide the basis for verification of the correctness of a tax settlement pursuant to the procedure of determining an overpayment. They correspond to the expiry of a tax liability through payment of a tax or collection thereof by a taxpayer or tax collector (Art. 59/1/1-2 of TOA) (Voivodeship Administrative Court: I SA/Sz 910/10). Thus, it is not possible for a taxpayer to effect a contractual transfer, to the State Treasury or a LGU, of the ownership of objects or property rights of a value higher than the amount of tax arrears and, then, to apply - pursuant to the procedure for tax overpayment - for a return of the overpayment resulting from the conducted operation.

Acknowledgment of the expiry of tax arrears or a respective part thereof (in the event when the value of objects or property rights is lower than the value of tax arrears) is effected in a formal manner, i.e. through issuing a decision by a tax authority of the first instance. The decision may be issued only on the date of transferring the ownership of an object or a property right because the date is considered the expiry date of a tax liability (Lewandowski, Pahl, 2012: 47). The role of a poviat governor within this scope is varied depending on whether a contractual transfer of the ownership of objects or property rights occurred in exchange for tax arrears on account of taxes constituting the revenues of the state budget or the poviat budget. In the first case, the decision acknowledging the expiry of tax arrears is issued by the competent head of a tax office, whereas in the second case, the decision is issued by a poviat governor, who, within the meaning of the provisions of TOA, is a tax authority of the first instance competent in the matters of public levies (taxes, fees, etc.) constituting the sources of poviat's own revenues. Thus, in the first case, there is a certain splitting of the role, since a poviat governor, concluding the agreement under discussion (representing the interests of he State Treasury as a part of performing a public task within the scope of government administration), does not have the competences to formally acknowledge the expiry of tax arrears mentioned in the content of the agreement. Only in the second case, a poviat governor is a party to the agreement transferring the ownership of objects or property right to 
A Poviat Governor as a Party to the Agreement Transferring the Ownership...

a poviat in exchange for tax arrears and, simultaneously, the entity Authorized to issue a decision acknowledging the expiry of such arrears.

\section{Conclusions}

Based on the applicable legislature, achievements of the doctrine and court rulings, all functions of a poviat governor performed in the case of applying a special manner of expiry of tax payer's tax arrears have been identified. A contractual transfer of the ownership of objects or property rights in exchange for tax payer's tax arrears due to the State Treasury or a LGU constitutes a form of a dialogue between the parties of a fiscal-legal relationship and, simultaneously, is included in the category of effective methods of cessation of a tax liability (Nita, 2014: 204-205). A poviat governor plays an important but varied role in this dialogue. In the case of applying this form of expiry of tax arrears on account of taxes providing revenues for the state budget, the dialogue is of a multilateral nature because the conclusion of the agreement requires a consent of the competent head of a tax office issued in the form of a decision. A refusal to give consent also requires the formation of a decision. Thus, a poviat governor maintains a dialogue with a taxpayer (its material expression is the agreement on transferring of the ownership of objects and property rights) as well as the head of a tax office (the material effect is the decision issued by the head of a tax office as regards consent or refusal to conclude the agreement).

The process of obtaining the consent is, thus, a manner of maintaining a dialogue between a poviat governor and the competent head of a tax office. A poviat governor formally represents the interests of the State Treasury, performing tasks within the scope of government administration, but, simultaneously, is a party to the agreement concluded with a taxpayer intending to lead, in this manner, to the expiry of tax arrears on account of taxes constituting the source of revenues of the state budget. As Art. 66 does not provide for any possibility of a taxpayer directly addressing the head of a tax office, a poviat governor also acts as an intermediary between the taxpayer and the head of a tax office requesting for issuing of a decision as regards expressing consent or refusal to give consent to conclusion of the agreement with the taxpayer. An application for issuing of such a consent is, nevertheless, filed after the conclusion of the agreement between the poviat governor and the taxpayer because pursuant to Art. 66/3a of TOA, the poviat governor notifies the competent head of a tax office of concluding the agreement and sends a copy thereof.

The order of poviat governor's activities adopted in TOA means that, first, an agreement is concluded between a taxpayer and a poviat governor and, then, a poviat governor requests the head of a tax office for a consent to conclude it. The decision issued is binding after the conclusion of the agreement subject to 
the condition precedent. For, its substantive effectiveness only has effects after a consent is expressed in the form of a decision. A refusal to transfer the ownership of objects or property rights to the State Treasury in exchange for tax liabilities on account of taxes constituting state budget revenues results in the ineffectiveness of the agreement. The decision of the head of a tax office acknowledging the expiry of tax arrears accomplishes a complex procedure of a special manner of tax payment, i.e. in the in-kind (material) form rather than pecuniary one.

In the case of a contractual transfer of the ownership of objects or property rights in exchange for tax arrears on account of public levies due to a poviat, the dialogue maintained with the participation of a poviat governor is simplified. A poviat governor concludes an agreement with a taxpayer independently. In this case, Art. 66 of TOA is a special regulation in relation to the provisions of Art. 12/8/a of PLGA regulating the exclusive competence of a poviat council to adopt resolutions in property matters concerning e.g. the principles of acquiring real property. A poviat governor is not obliged to obtain the consent of the poviat for the conclusion of an agreement with a taxpayer concerning a transfer of the ownership of objects or property rights to the poviat in exchange for tax arrears on account of public levies due to the poviat. A poviat governor, being simultaneously a tax authority, issues a decision acknowledging the expiry of tax arrears and, thus, accomplishes, in this manner, the procedure of tax payer's payment of the tax due in-kind (in a material form).

A poviat governor is the chairman of a poviat board and, i.e. a collective executive body of the poviat responsible for e.g. execution of the poviat budget (Art. 32/2/4 of PLGA). For proper execution of the poviat budget and, in particular, for maintaining of a budget balance and other framework arrangements determined in the budget resolution of a poviat council, it is necessary to collect revenues for the benefit of the poviat budget in the pecuniary form in order to secure the financial resources necessary for performance of public tasks financed from the budget. Excessive application of the use of in-kind (material) form of settlement of public levies, being an important form of poviat's revenues, could have a negative influence on the current financial balance and financial liquidity of the poviat budget. Within this scope, a poviat governor should permit the application of this form of settlement of public levies for the benefit of the poviat in a reasonable manner. The current practice indicates that contractual transfer of the ownership of objects and property rights in exchange for tax arrears on account of public levies whereto a poviat is entitled is a rare phenomenon and, thus, the danger does not have any real dimension.

To conclude, an agreement of a civil law nature concluded between a poviat governor and a taxpayer with a view to leading to effective expiry of tax arrears on account of public levies due to the State Treasury or the poviat is a precondition for 
A Poviat Governor as a Party to the Agreement Transferring the Ownership...

making of a sovereign administrative decision by the head of a tax office or a poviat governor, i.e. issuing of an administrative deed of a specific content (acknowledging the expiry of tax arrears). It is an obligatory administrative deed because a tax authority (the head of a tax office or a poviat governor) is obliged to act in a specific manner and issue a specific administrative deed (Mucha, 2008: 360-361).

\section{References}

Bielecki, L.: Starosta powiatu. Zarys charakterystyki prawnej (Poviat governor. Outline of legal characteristics), Rozprawy z Zakresu Nauk Prawnych (Dissertations in the Legal Science) no. 1 (2010).

Bielenik, T.: Przejęcie przez gminę mienia podatnika za zaległości podatkowe (Takeover by the municipality of taxpayer's property for tax arrears), Finanse Komunalne (Municipal Finance) no. 3 (2000).

Borszowski, P.: Przeniesienie własności na rzecz Skarbu Państwa (Transfer of ownership to the Treasury), Glosa (Gloss) no. 3 (2003).

Bouvier, M.: Wprowadzenie do prawa podatkowego i teorii podatku (Introduction to tax law and tax theory), Warszawa: KiK, 2000.

Brzezicki, T., Morawski, W.: Zakres przedmiotowy Ordynacji podatkowej w świetle orzecznictwa sądów administracyjnych (The scope of the Tax Ordinance Act in the light of the judicature of administrative courts), Przegląd Orzecznictwa Podatkowego (Review of Tax Jurisdiction) no. 6 (2009).

Brzeziński, B., Olesińska, A.: Podstawowe instytucje ogólnego prawa podatkowego (Basic institutions of general tax law), in: Nykiel, W., Wilk, M.: Zagadnienia ogólne prawa podatkowego (General tax law issues), Łódź: Fundacja Centrum Dokumentacji i Studiów Podatkowych, 2014.

Brzeziński, B.: Wstęp do nauki prawa podatkowego (Introduction to tax law), Toruń: TNOiK, 2001.

Burzyński, J.: Zaległości podatkowe jako potencjalne źródło dochodów w gminach (Tax arrears as a potential source of income in communes), Przegląd Podatków Lokalnych i Finansów Samorządowych (Review of Local Taxes and Local Government) no. 11 (2012).

Ciecierski, M.: Glosa do uchwały NSA z dnia 7 grudnia 2009 r., II FPS 5/09 (Gloss to the resolution of the Supreme Administrative Court of 7 December 2009), Glosa (Gloss) no. 4 (2011).

Dauter, B.: Efektywne sposoby wygasania zobowiązań podatkowych (Effective means of terminating tax liabilities), Doradztwo Podatkowe (Tax Advisory) no. 5 (2002).

Dolnicki, B.: Monokratyczne organy samorządu terytorialnego (Monocratic territorial selfgovernment bodies), Samorząd Terytorialny (Local Self-government) no. 1-2 (2003).

Drela, M.: Przeniesienie praw majątkowych nieruchomości zabezpieczonej hipoteką umowną łączną zwykłą na rzecz Skarbu Państwa na podstawie art. 66 Ordynacji podatkowej (Transfer of property rights secured by a joint contractual mortgage ordinary to the Treasury pursuant to 
art. 66 Tax Ordinance Act), Nowe Zeszyty Samorządowe (New Self-Government Notebooks) no. 2 (2014).

Etel, L.: Komentarz do art. 53 (Comment on art. 53), in: Etel, L. (ed.): Ordynacja podatkowa. Komentarz (Tax Ordinance. Comment), Warszawa: Wolters Kluwer, 2017.

Gomułowicz, A.: Aspekt prawny podatku (Legal aspect of tax), in: Gomułowicz, A., Mączyński, D.: Podatki i prawo podatkowe (Taxes and tax law), Warszawa: Wolters Kluwer, 2016.

Gomułowicz, A.: Glosa do uchwały NSA z dnia 8 października 2007 r., I FPS 2/07 (Gloss to the resolution of the Supreme Administrative Court of 8 October 2007, I FPS 2/07), Orzecznictwo Sądów Polskich (Jurisprudence of Polish courts) no. 5 (2008).

Huchla, A.: Regulowanie zobowiązań podatkowych w szczególny sposób (Regulating tax liabilities in a special way), Nowe Zeszyty Samorządowe (New Local Government Notebooks) no. 5 (2000).

Lewandowski, P., Pahl, B.: Wygaśnięcie zobowiązania podatkowego wskutek przeniesienia własności rzeczy lub prawa majątkowego na rzecz gminy (Termination of tax liability due to the transfer of ownership of property or property right to a commune), Finanse Komunalne (Local Self-government) no. 5 (2012).

Morawski, W.: Przeniesienie własności rzeczy i praw majątkowych w zamian za zaległości podatkowe (Transfer of ownership of property and property rights in exchange for tax arrears), Monitor Podatkowy (Tax Review) no. 8 (1998).

Mucha, M.: Umowy o przeniesienia własności rzeczy lub praw majątkowych w zamian za zobowiązania podatkowe (Agreements on the transfer of ownership of property or property rights in exchange for tax liabilities), in: Boć, J., Dziewięcka-Bokun, L. (eds.): Umowy w administracji (Agreements in administration), Wrocław: Kolonia Limited, 2008.

Niemczuk, P.: Pozycja ustrojowo-prawna starosty (Legislative and legal position of the poviat governor), Administracja (Administration) no. 1 (2011).

Nita, A.: Porozumienia w prawie podatkowym. Horyzontalne metody determinacji powinności podatkowej (Agreements in tax law. Horizontal methods of tax liability determination), Warszawa: Wolters Kluwer, 2014.

Olesińska, A.: Glosa do wyroku NSA z dnia 28 sierpnia 2008 r., I FSK 972/07 (Gloss to the judgment of the Supreme Administrative Court of 28 August 2008, I FSK 972/07), Przegląd Orzecznictwa Podatkowego (Review of Tax Jurisdiction) no. 2 (2009).

Siemieniako, J.: Charakter prawny umowy zawartej w trybie art. 66 Ordynacji Podatkowej (Legal character of the contract concluded in the mode of art. 66 of the Tax Code), Finanse Komunalne (Municipal Finance) no. 1-2 (2008).

Ślifirczyk, M.K.: Przeniesienie własności rzeczy lub praw majątkowych na rzecz Skarbu Państwa (gminy) (Transfer of ownership of property or property rights to the State Treasury (community)), Doradztwo Podatkowe (Tax Advisory) no. 4 (1998).

Wołowiec, T.: Przeniesienie własności rzeczy lub praw majątkowych spółki na rzecz wierzyciela podatkowego jako forma wygaśnięcia zobowiązań podatkowych (Transfer of ownership of property or property rights of the company to the benefit of the tax creditor, as a form of 
A Poviat Governor as a Party to the Agreement Transferring the Ownership...

expiration of tax liabilities), Przegląd Ustawodawstwa Gospodarczego (Review of Economic Legislation) no. 8 (2012).

PL: Act of 17 May 1989, on Geodetic and Cartographic Issues, as amended.

PL: Act of 20 June 1997, on Road Traffic Law, as amended.

PL: Tax Ordinance Act of 29 August 1997, as amended.

PL: Act of 5 June 1998, on Poviat Local Government, as amended.

PL: Act of 27 April 2001, on Environmental Protection Issues, as amended.

PL: Act of 13 November 2003, on Revenues of Local Government Units, as amended.

PL: Act of 9 June 2011, on Geological and Mining Issues, as amended.

PL: Supreme Administrative Court: I FPS 2/07.

PL: Supreme Administrative Court: I FSK 501/06.

PL: Supreme Administrative Court: I FSK 434/10.

PL: Supreme Administrative Court: I FSK 1635/10.

PL: Supreme Administrative Court: I FSK 555/13.

PL: Supreme Administrative Court: II FSK 3066/14.

PL: Supreme Administrative Court: II FW 2/14.

PL: Voivodeship Administrative Court: II SA/Łd 1518/03.

PL: Voivodeship Administrative Court: III SA/Wa 2972/05, LEX no. 194038.

PL: Voivodeship Administrative Court: III SA/Wa 861/10.

PL: Voivodeship Administrative Court: I SA/Sz 910/10.

PL: Voivodeship Administrative Court: SA/Po 846/10.

PL: Voivodeship Administrative Court: III SA/GI 1312/12.

PL: Voivodeship Administrative Court: I SA/Po 718/13.

PL: Voivodeship Administrative Court: I SA/Rz 67/14.

PL: Voivodeship Administrative Court: I SA/Sz 1212/14.

PL: Voivodeship Administrative Court: I SA/GI 552/16. 